\title{
The first map of salt deposits in Romania (1780). Current corresponding toponyms ${ }^{\dagger}$
}

\author{
Dinu Moscal* \\ Department of Interdisciplinary Research in Social Sciences and Humanities, "Alexandru Ioan Cuza" University, \\ Str. Lascăr Catargi 54, 700107 Iaşi, Romania \\ “A. Philippide” Institute of Romanian Philology, Str. Th. Codrescu 2, 700481 Iaşi, Romania
}

\section{Article info}

History:

Received October 29, 2017

Accepted November 20, 2017

Published November 30, 2017

Key words:

salt deposits

salt springs

Carpathians

toponymy

Fichtel's map (1780)

\begin{abstract}
The history of salt exploitation in the Carpathian arc area is far from being complete regarding certain periods of Romania's historical provinces, although a lot has been written on this topic. A map of the salt deposits drafted in 1780 represents one of the most important achievements in this field. One of the mandatory aspects of this historical approach is the identification of places from where salt is or was extracted. Following a short history of the primary documentations of the exploitation of salt on the territory of Romania, this study presents Fichtel's (1780) contribution to identifying the salt deposits on this territory. The updating of the toponyms on the map poses no difficulties for the historical provinces Moldavia and Wallachia, yet the situation is different in the case of the toponyms in Transylvania, since the nomenclature from the Hungarian domination period (until 1918) was mostly modified starting with the year 1919. Correspondences from the current nomenclature were provided for all these toponyms. The study offers an update of the localization of salt wells or springs and sedimentary deposits of salt, as indicated by Fichtel, by identifying present corresponding toponyms for the ones indicated on the map.
\end{abstract}

\section{A brief history}

The salt deposits in the Carpathian arc are the biggest in Europe, which explains why the interest in them spread beyond the local population, the exploitation of these salt deposits becoming one of the main objectives of the empires that once dominated parts of this region. The first written information relating to the exploitation of salt in the Carpathian arc dates from the Roman Dacia. The importance of the salt is indicated by the fact that its exploitation was an imperial privilege and that the emperor would lease the salt mines to some Roman officials (conductores), often together with the right to pasture and sometimes the right to sell the exploited salt, as shown by the epigraphic sources dating from the beginning of the $3^{\text {rd }}$ century A.D.: "conductor pascui, salinarum et commerciorum" (CIL III, 1209 [IDR III/5, 443]) or "conductor pascui et salinarum" (CIL III, 1363 [ID R III/3, 119]; Dana \& Zăgreanu, 2013, p. 28-32, cf. also Mihăilescu-Bîrliba, 2016, p. 57; Fischer, 1921, p. 71; cf. also Christescu, 2004, p. 49), but also only "conductor salinarum" (IDR III/4, 248; Piso, 2004-2005, p. 179-182, cf. also Mihăilescu-Bîrliba, 2016, p. 55-57). We have very little knowledge about the way in which the Romans used to administer the exploitation of salt (cf. Wollmann, 1996, p. 248-249), yet we can easily assume that they were very likely to have a map or a repertoire of the places from where salt was extracted or where the salt deposits were located. We know for sure that the only official documentation of a salt exploitation area from that period is contained in Tabula Peutingeriana, where there occurs the indication in the ablative Salinis (on the map

\footnotetext{
${ }^{\dagger}$ This work was supported by a grant of Ministery of Research and Innovation, CNCS-UEFISCDI, project number 151/2017, PN-III-P4-ID-PCE-2016-0759, within PNCDI III.

*Email address: dinu.moscal@gmail.com.
} 
in the sequence Blandiana - Apula - Brucla - Salinis - Potavissa - Napoca), noted on the most important Roman route in Dacia, which crossed an area with valuable natural resources. The toponym was difficult to localize, even for Theodor Mommsen, who points out that it cannot refer to Turda, as previously believed (Zamosius, 1593, p. 78; Opitz, 2009, p. 801, 803; Ackner \& Müller, 1865, p. 138). He identifies it with Felvincz, that is Vințul de Sus, known today as Unirea in the county of Alba (CIL III, p. 172, 177), and not with Ocna Mureș and Uioara de Sus, situated on the other side of River Mureș. Mommsen brings forward the issue of the accurate localization, Maros-Újvár-which corresponds to the present-day localities Ocna Mureș and Uioara de Sus—, yet he only mentions it as a reference point for Felvincz: "Felvincz [...] a salinis quæ etiamnunc durant ad vicum proximum Maros-Ujvár" (CIL III, p. 177). The correspondence SalinisMaros-Újvár-Ocna Mureș and Uioara de Sus is confirmed by the traces of Roman exploitation discovered here, first attested by Ackner (1856, p. 23; see also Christescu, 2004, p. 49; Wollmann, 1996, p. 241).

References to salt and its exploitation in the present territory of Romania appeared in various sources starting with the year 892 (CDEM I, p. 52; see also Maghiar \& Olteanu, 1970, p. 97 ff.); the very first document from the feudal era referring to Transylvania, from the year 1075, is related to the salt mines (DIR,C I, p. 1). Of the multitude of bibliographic references related to this topic we mention here just a few works that treat from a general perspective the history of salt exploitation and its economic and social impact in the Romanian area: Doboși (1951), Pascu (1986, p. 246-259), Vitcu (1987), Wollmann (1996), Ciobanu (2002). The first map of the salt mines and salt deposits (salt wells or springs and sedimentary deposits of salt) in Romania - focusing on the intra-Carpathian area, Transylvania-was only drawn during the Austro-Hungarian empire domination (the right to exploit salt was among the royal rights of the empire), in Fichtel's study (1780), regularly quoted in the literature on the field. Although the localization of salt pits and salt deposits does not have difficulties comparable with the case in Taubula Peutingeriana (Saline is also identified with Turda in Fichtel, 1780, p. 89), the indicated toponyms are not always easy to identify within the present nomenclature. This is not the case with the ones from the extra-Carpathian area, where one only deals with transliterations. The objective of this study is to correlate the toponyms indicated by Fichtel-noted mostly with their Hungarian or sometimes German correspondents-with present-day toponyms. Some of these shall prove useful when consulting certain works published before 1918, such as Ackner (1856), Ackner \& Müller (1865) sau Gooss (1876, p. 264-330).

\section{Fichtel's map}

The study of mineralogist Fichtel represents the first notable work dedicated to salt deposits in Romania, despite the fact that the extra-Carpathian area is only represented by the most important salt pits and deposits. The high degree of accuracy of the data provided is definitely due to direct investigation (Fichtel, 1780, p. 6-7). Moreover, the study represented a report for the Vienna administration, drafted with the aim of organising the exploitation of salt in Transylvania by the Austro-Hungarian administration. The author actually emphasizes the economic importance of the salt, stating that it is more important than the gold in Transylvania: "das Salz füllet auch den Seckel des Staats weit reichlicher, als selbst die siebenbürgische Golderzeugung” (Fichtel, 1780, p. 6-7).

The map localizes the pits under construction, unexploited sedimentary deposits of salt ("Salzspurien”), salt wells and springs, yet it ignores the existence of salt blocks ("Salzlecke"), which are regarded as irrelevant as far as the quantity of salt in those specific places is concerned (Fichtel, 1780, p. 29). The fact that the presence of these salt blocks was omitted on purpose is easy to explain, since the ultimate objective of the map was to ensure an efficient exploitation of salt deposits. Among other specifications regarding the salt deposits map there occurs a correction of the border between Romania and Poland, which in previous maps was, according to Fichtel, about 15-20 German miles more advanced towards the South-East, on the limit where it encounters the Dniester River.

As far as the pits under exploitation are concerned, the most important are described in a separate subsection and some others in special sub-sections (Ocna Dej and Ocna Sibiului in $\$ 8$ and $\S 9$, respectively). 
They are enumerated together with the others, according to their regions, in the subsequent sub-sections $(\$ 10-\$ 13)$, while punctual references regarding various aspects occur throughout the study. One must note that the objective of the map is to represent unexploited deposits since this map, as a study, aims at extending the exploitation of salt. The unexploited deposits are marked with three categories of symbols: pits under construction (green surface square), unexploited sedimentary deposits of salt (green surface circle), and salt springs, namely wells and springs (red surface circle). Thus, the author says in relation to Visakna, that is Ocna Sibiului, that he counted fifteen pits, to which the ones under construction are to be added (Fichtel, 1780, p. 89-90), yet on the map there are the symbols for pits under construction (two) and for salt springs (one).

\title{
3. Observations regarding the toponyms
}

Unexploited salt deposits are mostly represented by identifying localities in their vicinity, only a few being near a river bed, near a certain mountain or in the area of a mountain passage. In the case of some localities (for example KIS SÁROS <KISS-SÁROS〉, County of Târnava) the Romanian equivalent (Șaroșul Mic) was replaced in the meanwhile by the new administrations. In such situations the Romanian equivalent will be listed as the proper equivalent, followed by the present equivalent (Delenii), with the specification "today" (KIS SÁROS <KISS-SÁros>, comitatul Tîrnava - Șaroșul Mic, today Delenii, c. Băgaciu, Mureș). The toponyms are also presented separately by Fichtel (1780, p. 130-134) in a repertoire preceding the map, yet in some cases there is no perfect correspondence between the forms. In such cases they are placed between angle brackets according to their form on the map. The repertoire preceding the map also contains some toponyms that are not written on the map. These are placed between angle brackets. Whenever there occurs in the repertoire a name synonymous with the one on the map, a separate entry will designate the name on the map. In the case of versions of graphic deformations on the map, no additional entries shall be opened. Oikonyms from Transylvania also have in the repertoire the indication of the county, the seat or the district they belong to, which we transcribed immediately after the oikonym. For the present equivalent oikonym we indicated the commune it belongs to, using the abbreviation "c." (except for the cities), followed by the name of the county. For the few rivers we only indicated the river into which they flow, except for the river Vrancea, which is a synonym for the upper flow of river Putna. For mountains and mountain passages we only indicated the present equivalent. For salt mines we provided localization according to the nomenclature of the current administration.

The toponyms will be listed in alphabetical order with their present correspondents, keeping separate, however, their renderings for the three historical regions of Romania.

\section{Repertoire of the toponyms with their present correspondents}

\section{Wallachia}

FOCSIAN $<$ FOCRIAN $>-$ City of Focșani, Vrancea.

OKNA KIMPINA <OKNA BEY KIMPINA> - Ocna Cîmpina "Cîmpina Salt Mine”, near City of Cîmpina, Prahova.

OKNA RIMNIK < OKNA BEY RIMNIK> - Ocna Rîmnic "Rîmnic Salt Mine", today Ocnele Mari "Large Salt Mines", near City of Ocnele Mari, Vîlcea.

Teleaga <OKNa teleaga > Ocna Telega “Teleaga Salt Mine”, near Telega, c. Telega, Prahova.

TERGOVISTA < TERGOVIST > - City of Tîrgoviște, Dîmbovița.

\author{
Moldavia \\ GROZESD - Grozești, today Oituz, c. Oituz, Bacău. \\ HERSAN - Hîrja, c. Oituz, Bacău. \\ KRUTZE $<$ KRUTSE $>-$ Crucea, c. Crucea, Suceava.
}


LIPSE BACH <LIPSE FLUSS> - Lepșa Creek, left tributary of Putna River.

M[ONS] KETSKETS < KECSKÉShHAVAS> - Mount Cheșcheș.

M[ONS] KIS HAVAS < KISS HAVAS > - Mount Haoșul Mic.

M[ONS] SIROS - Mount Jiroş.

OJTOS FL[Uss] - Oituz Creek, right tributary of Trotuș River.

OKNA < MOLDAUISCH OKNA > Ocna Moldovei “Moldavian Salt Mine", today Salina Tîrgu Ocna, near City of Tîrgu Ocna, Bacău.

PASSUS GYÉmes - Ghimeș Pass.

PASSUS OJTOS - Oituz Pass.

PURTIESTJ < PORTIESTI > Pîrteștii [de Sus], c. Cacica, Suceava.

SZLATINA <SLATINA > Slatina, c. Slatina, Suceava.

SZUTSAVITZA <SZUTSOVITZA > Sucevița, c. Sucevița, Suceava.

VARANTZA PUTNA FL[USS] <WRANTSA PUTNA FLUSS > - Vrancea River, the upper flow of Putna River. ZABOLA PUTNA FLUSS - Zăbala Creek, right tributary of Putna River.

\section{Transylvania}

<ALSO-BORGO> see J[OSENI?] BORGO.

A[LSÓ] IDETS, County of Turda - Ideciul de Jos, c. Ideciul de Jos, Mureș.

<ALSO-RÁKOSD>, County of Alba - Racoșul de Jos, c. Rupea, Brașov.

A[LSÓ] SUK <ALSO-SUG >, County of Cluj - Jucu de Jos, c. Jucu, Cluj.

ABOCSFALVA <ABOSFALVA>, Seat of Odorhei - Aldea, c. Mărtiniş, Harghita.

almas, Seat of Odorhei - Merești, c. Merești, Harghita.

ASZn BeSZTERIZE <ASZu BeSZlerCZE>, District of Bistrița - Dorolea, c. Livezile, Bistrița Năsăud.

BALASF [Á]L[VA], County of Dăbîca - Blăjenii de Jos, c. Șintereag, Bistrița Năsăud.

BALla, County of Turda - Băla, c. Băla, Mureș.

BATOs, County of Cluj - Batoș, c. Batoș, Mureș.

BELLÁK <BILlAK>, County of Dăbîca - Bileag, today Domnești, c. Mărișelu, Bistrița Năsăud.

Bethlen, County of Solnocul Interior - City of Beclean [pe Someș], Bistrița Năsăud.

BONTZ NYIRES < BONCZ-NYIRES>, County of Dăbîca - Bonț, c. Fizeșu Gherlii, Cluj.

BORZAS, comitatul Tîrnava - Boziaş, quarter of the City of Tîrnăveni, Mureș.

вÖZzOD < ВÖSÖSD >, Seat of Odorhei - Bezid, suburbs of the City of Sîngeorgiu de Pădure, Mureș.

<BUZAS-BOCSARD>, County of Alba - Bucerdea Grînoasă, c. Bucerdea Grînoasă, Alba.

CSEPAN, County of Solnocul Interior - Cepan, today Cepari, c. Dumitra, Bistrița Năsăud.

DEES, County of Solnocul Interior - Dej, Cluj.

DEESÖKNA <DESAKNA >, County of Solnocul Interior - Ocna Dejului, component locality of the City of Dej, Cluj.

DEZMER < DESMÉR>, County of Cluj - Dezmir, c. Apahida, Cluj.

$<$ DÖGMEZÖ $>$, see K[IS] DÖGMEZÖ.

DRAGOM[IRFA $]$ LV [A] <DRAGOMIR>, County of Maramureș - Dragomirești, Maramureș.

ERDÖ SZAKAL <ERDÖSSAKAL >, County of Turda - Săcalu de Pădure, c. Brîmcovenești, Mureș.

FEJEREgYhaZ <FEHÉREgYháZA〉, District of Bistrița - Albeștii Bistriţei, c. Galații Bistriței, Bistrița

Năsăud.

FEKeTElaK, County of Dăbîca - Negrenii de Cîmpie, c. Band, Mureș.

FElsö ваJом, Seat of Mediaș - Boianul de Sus, today Bazna, c. Bazna, Sibiu.

F[ELSÖ] BORGo, County of Dăbîca - Susenii Bîrgăului, c. Prundu Bîrgăului, Bistrița Năsăud.

F[ELSÖ] SUK <FELSÖ-SUG〉, County of Cluj - Jucu de Sus, c. Jucu, Cluj.

$<$ Fiat FalVA>, Seat of Odorhei - Filiași, suburbs of the City of Cristuru Secuiesc, Harghita.

FÜGE, County of Solnocul Interior - Figa, suburbs of the City of Beclean [pe Someș], Bistrița Năsăud.

GALD, Seat of Rupea - Ungra, c. Ungra, Brașov. 
<GaLfalva>, County of Tîrnava - Gănești, c. Gănești, Mureș.

GARAD (Hung. Garat, after Germ. Stein), Seat of Rupea - Ștena, today Dacia, c. Jibert, Brașov.

GRID, County of Hunedoara - Grid, c. Pîrău, Brașov.

<GÜrgenY-Groszfalu (= Görgény Oroszfalu)>, County of Turda - Solovăstru, c. Solovăstru, Mureș.

GYEPES < KOPIS >, Seat of Odorhei - Ghipeș, c. Mărtiniș, Harghita.

HADAT, County of Solnocul Interior - Hodod, c. Hodod, Satu Mare.

HESDAAD < HÉSDÁT>, County of Turda - Hăşdate, c. Săvădisla, Cluj.

HESTAD <HÉSDÁT>, County of Dăbîca - Hășdate, suburbs of the City of Gherla, Cluj.

HOLDAU < HELTAU>, Seat of Sibiu - Cisnădie, Sibiu.

$<$ IKLOD $>$, County of Alba - Iclod, c. Sîncel, Alba.

JAD <IAAD >, District of Bistrița - Livezile, c. Livezile, Bistrița Năsăud.

J[OSENI?] BORGO, <ALSO-BORGO>, County of Dăbîca - Josenii Bîrgăului, c. Josenii Bîrgăului, Bistrița Năsăud.

KAIla <KAYLA >, County of Dăbîca - Caila, c. Șintereag, Bistrița Năsăud.

Karatsonfalva, Seat of Odorhei - Crăciunel, c. Ocland, Harghita.

KEMENYFALVA < HOMOROD-KEMÉNYFALVA>, Seat of Odorhei - Chemenfalău Homorodului, today

Comănești, c. Mărtiniş, Harghita.

KendTElKe < KentelKe>, County of Dăbîca - Chintelnic, c. Șieu-Măgheruș, Bistrița Năsăud.

Kereszturf $[\mathrm{A}] \mathrm{L}[\mathrm{VA}]$, Seat of Odorhei - Cristuru, today in the City of Cristuru Secuiesc, Harghita.

KINTSES, County of Turda - Comori, c. Gurghiu, Mureș.

KIS AKNA, County of Alba de Jos - Ocnișoara, c. Lopadea Nouă, Alba.

K[IS] DÖGMEZÖ < DÖGMEZÖ>, County of Solnocul Interior - Dumbrăvița, c. Spermezeu, Bistrița Năsăud.

K[IS] KAIAN <KIS-KAJON>, County of Solnocul Interior - Căianu Mic, c. Căianu Mic, Bistrița Năsăud.

KIS SÁROS <KISS-SÁROS>, County of Tîrnava - Șaroșul Mic, today Delenii, c. Băgaciu, Mureș.

KISfALU, County of Dăbîca - Măgurele, c. Mărișelu, Bistrița Năsăud.

$<$ KISS-AlmaS〉, County of Alba - Almașul Mic de Munte, c. Balșa, Hunedoara.

< KISS-OESKÜLlÖ>, County of Dăbîca - Așchileu Mic, c. Așchileu, Cluj.

kólos, County of Cluj - Cojocna, c. Cojocna, Cluj.

KOROND, Seat of Odorhei - Corund, c. Corund, Harghita.

KÖSZv[ÉNYES] <KÖSSVÉNYES〉, Seat of Mureș - Eremitu, c. Eremitu, Mureș.

KÖTELEND, County of Cluj - Gădălin, c. Jucu, Cluj.

KÖVAR, District of Chioar - [Cetatea] Chioar[ului], near Berchezoaia, c. Remetea Chioarului, Maramureș.

KÖzepf $[\mathrm{A}] \mathrm{L}[\mathrm{VA}]$, County of Solnocul Interior - Chiuza, c. Chiuza, Bistrița Năsăud.

KUKÜLlÖ KEMENyF[AL]v[A], Seat of Odorhei - Tîrnovița, c. Brădești, Harghita.

KÜKÜLlovar, County of Tîrnava - Cetatea de Baltă, c. Cetatea de Baltă, Alba.

LÉTKA, District of Chioar - Letca, c. Letca, Sălaj.

LÖveTE, Seat of Odorhei - Lueta, c. Lueta, Harghita.

<MAgosmarT >, County of Solnocul Interior - Mogoșeni, c. Nimigea, Bistrița Năsăud.

MAGYARos, County of Dăbîca - Măgheruș, today Șieu-Măgheruș, c. Șieu-Măgheruș, Bistrița Năsăud.

magyaros, County of Turda - Aluniș, c. Aluniş, Mureș.

MALlOMARKa <MALOMÁRKA>, District of Bistrița - Monariu, c. Budacu de Jos, Bistrița Năsăud.

MÁLON <MALOM〉, County of Solnocul Interior - Malin, c. Nușeni, Bistrița Năsăud.

MAROS UIVAR <MAROSUjVAR>, County of Alba - Ocna Mureș, Alba.

MEZÖ MADARAs, Seat of Mureș - Fînațele Mădărașului, c. Mădăraș, Mureș.

Mihalika, County of Maramureș - Ocna Mihai, near Ocna Șugatag, c. Ocna Șugatag, Maramureș.

MikehaZo <MikeHaZA , County of Solnocul Interior - Mica, c. Mica, Cluj.

MIKes, County of Turda - Micești, c. Tureni, Cluj.

N[AGY] Demeter, District of Bistrița - Dumitra Mare, today Dumitra, c. Dumitra, Bistrița Năsăud. 
NAGY ERNYE < NAGY-ERENYE >, Seat of Mureș - Ernei, c. Ernei, Mureș.

N[AGY] IDA, County of Cluj - Ida Mare, today Viile Tecii, c. Teaca, Bistrița Năsăud.

<NAGY-KAJON>, County of Solnocul Interior - Căianu Mare, c. Căianu Mic, Bistrița Năsăud.

NAGY-LOZNA <NAGY LÓSSNA>, County of Solnocul Interior - Lozna, c. Lozna, Sălaj.

N[AGY] OSKÜlla <NAGY OESKÜLlo>, County of Dăbîca - Așchileu Mare, c. Așchileu, Cluj.

NEMEgYe <MAGYAR-NemegYe and OlAh-NEMEgYe>, County of Solnocul Interior - Nimigea Ungure-

ască, today Nimigea de Jos, and Nimigea Romînească, today Nimigea de Sus, c. Nimigea, Bistrița Năsăud.

NET < NÉZ >, County of Dăbîca - Neț, today Nețeni, c. Mărișelu, Bistrița Năsăud.

$<$ OLAH PINTEK>, County of Cluj - Pintic, suburbs of the City of Dej, Cluj.

OKNITZA <SZASZAKNA >, County of Cluj - Ocnița, c. Teaca, Bistrița Năsăud.

<OROSZ-BORGO〉, see RUSZ-BORGO.

orsova, County of Turda - Orșova, c. Gurghiu, Mureș.

OVASZFALA <Görgéni-OROSZFALU> [= Oroszfája], County of Turda - Orosfaia, c. Milaș, Bistrița Năsăud.

PARAJD < PARAYD>, Seat of Odorhei - Praid, c. Praid, Harghita.

PASSUS BOOZA - Buzău Pass.

PASSUS RODNA - Rodna Pass.

Pass[us] Tömös - Timiș Pass, today Predeal Pass.

PASSUS TORZBURG - Bran Pass (Torzburg - Turciu, today Bran, c. Bran, Brașov).

PASZMOS <PASSMOS>, County of Cluj - Posmuş, c. Șieu, Bistrița Năsăud.

Pata, County of Cluj - Pata, c. Apahida, Cluj.

PERSAN, County of Hunedoara - Perșani, c. Șinca, Brașov.

$<$ Peterfalva $>$, County of Tîrnava - Petrisat, suburbs of the City of Blaj, Alba.

peterfalva, County of Alba - Petiș, c. Șeica Mare, Sibiu.

PINTAK <SZASZ-PINTEK>, District of Bistrița - Pinticu, c. Teaca, Bistrița Năsăud.

REMETE, District of Chioar - Remetea Chioarului, c. Remetea Chioarului, Maramureș.

REMETE, Seat of Mureș - Remetea, suburbs of the City of Tîrgu Mureș, Mureș.

REPS, Seat of Rupea - Rupea, Brașov.

RETSEnyed, Seat of Odorhei - Rareș, c. Mărtiniş, Harghita.

RHENASZEK < RHONASZEK>, County of Maramureș - Coștiui, c. Rona de Sus, Maramureș.

ROThe Thurn Pass[us] - Turnul Roșu Pass.

RUSZ-BORgo <Orosz-BORgo>, County of Dăbîca - Rusul Bîrgăului, c. Prundul Bîrgăului, Bistrița Năsăud.

<SAJO Keresstur>, County of Dăbîca - Cristur-Șieu, c. Șieu-Odorhei, Bistrița Năsăud.

<SAJO-UdVARHELY>, County of Solnocul Interior - Șieu-Odorhei, c. Șieu-Odorhei, Bistrița Năsăud.

SAMSAND <SAMSON>, Seat of Mureș - Șamșond, today Șincai, c. Șincai, Mureș.

SEPTER, County of Cluj - Șopteriu, c. Urmeniş, Bistrița Năsăud.

$<$ SOAKNA〉, See SZABANITZA.

SOM KER[EK] <SOMKEREK>, County of Solnocul Interior - Șintereag, c. Șintereag, Bistrița Năsăud.

SOMKuT, County of Solnocul Interior - Șomcutul Mic, suburbs of the City of Dej, Cluj.

SOOFAlva <Sófalva〉, Seat of Odorhei - Ocna, today Ocna de Sus and Ocna de Jos, c. Praid, Harghita.

SOSPATAK < SOOSPATAK>, County of Turda - Șăușa, suburbs of the City of Ungheni, Mureș.

SOVAROD, Seat of Mureș - Sovarod, c. Sovarod, Mureș.

SZABAD, Seat of Mureș - Săbed, c. Ceaușu de Cîmpie, Mureș.

SZABANITZA < SOAKNA (= Görgénysóakna)>, County of Turda - Jabenița, c. Solovăstru, Mureș.

sZ[ásZ] NYIRES, County of Solnocul Interior - Nireș, c. Mica, Cluj.

$<$ SZASZ-PINTEK $>$, see PINTAK.

SZASZ REgEN, County of Turda - Reghinul Săsesc, today Reghin, Mureș.

<SZASZAKNA>, see OKNITZA. 
sZEK, County of Dăbîca - Sic, c. Sic, Cluj.

<SZENT-ANDRÁS>, County of Dăbîca - Șieu-Sfîntu, c. Șintereag, Bistrița Năsăud.

S[ZEN]T IMREH <GÖRGÉni-SZENT IMRE/SZENT-IMRE>, County of Turda - Sîntimbru, c. Sîntimbru, Harghita.

s[zent] MARgitTa, County of Solnocul Interior - Sînmărghita, c. Mica, Cluj.

sz[ent] Marton, Seat of Ciuc - Sînmartin, c. Sînmartin, Harghita.

<SZENT-MARTON>, County of Turda - Mărtinești, c. Tureni, Cluj.

s[ZEN]T MARTON < HOMOROD-SZENT MÁRTON>, Seat of Odorhei - Mărtiniş, c. Mărtiniş, Harghita.

$s[$ ZEN]T MIKLOS <SCENT MIKLOS>, County of Tîrnava - Sînmiclăus,, c. Șona, Alba.

SZ[EN]T PALL <HOMOROD-SZENT PAL >, Seat of Odorhei - Sînpaul, c. Mărtiniș, Harghita.

S[ZEN]T PETER < HOMOROD-sZEnT PÉTER>, Seat of Odorhei - Petreni, c. Mărtiniş, Harghita.

SZEPLAK, County of Solnocul Interior - Bunești, c. Mintiu Gherlii, Cluj.

<SZESZARMA >, County of Solnocul Interior - Săsarm, c. Chiuza, Bistrița Năsăud.

Szimontelke <Simontelke>, County of Dăbîca - Simionești, c. Budacu de Jos, Bistrița Năsăud.

SZITAS KereszTUR, Seat of Odorhei - Cristuru Secuiesc, Harghita.

szombattelke, County of Dăbîca - Sîmboieni, c. Sînmărtin, Cluj.

Szotelke <SótelKe>, County of Dăbîca - Sărata, c. Panticeu, Cluj.

SZOTZ BANYITZA <SZASZ-BANITZA〉, County of Cluj - Băița, c. Lunca, Mureș.

Szovatha $<$ Szovata $>$, Seat of Odorhei - Sovata, Mureș.

TEKE <TEKENDORFF>, County of Cluj - Teaca, c. Teaca, Bistrița Năsăud.

THORDA, County of Turda - Turda, Cluj.

TOHAT, County of Alba de Jos - Tohat, suburbs of the City of Ulmeni, Maramureș.

тонат, County of Solnocul Interior - Tăure, c. Nimigea, Bistrița Năsăud.

TOR[PÉNY] <TREPPEN>, District of Bistrița - Tărpiu, c. Dumitra, Bistrița Năsăud.

$<$ TREPPEN>, SEe TOR[PÉNY].

UDVARHELly, Seat of Odorhei - Odorheiu Secuiesc, Harghita.

VAjOla < WOJOLA >, County of Cluj - Voila, today Uila, c. Batoș, Mureș.

VET <WETS >, County of Turda - Brîncovenești, c. Brîncovenești, Mureș.

VINDA <WAAD >, District of Bistrița - Vinda, today Ghinda, component locality of the City of Bistrița, Bistrița Năsăud.

< VIRÁGOSBEREK>, County of Solnocul Interior - Vireag, today Florești, Bistrița Năsăud.

viszakna, County of Alba de Jos - Ocna Sibiului, Sibiu.

ZEREDfada <SzeRetfalva〉, County of Dăbîca - Serețel, today Sărățel, c. Șieu-Măgheruș, Bistrița Năsăud.

\section{Salt mines, sedimentary deposits of salt and salt springs}

The repertoire preceding the map is also organized according to the type of deposit and the existence of salt mines, without specifying their number, however. Fitchel himself noted this detail, as well as the difficulty in indicating an exact number of deposits, as shown in the presentation of the Visakna mines (Fichtel, 1780 , p. 89-90, see supra, \$2). However, the map often indicates several salt water springs ("Salzbrunnen”, that is springs or wells) or unexploited sedimentary deposits of salt. In order for the data provided by Fichtel to be available for use in identifying salt water springs, they will be enumerated in alphabetical order, preserving the already presented forms. For the ones that appear only on the map, we indicated between brackets the specification "map only" as well as the indicated number of springs and sedimentary deposits of salt. For the areas that do not appear on the map section included in Appendix A, we have specified the number of salt springs or sedimentary deposits of salt if they were already included in that particular section (for salt water springs "Salzbrunnen", and respectively unexploited sedimentary deposits of salt "Salzspurien"). For the same areas, when a toponym listed in the repertoire under a single category 
Dinu Moscal

for which the map also indicates the existence of a deposit belonging to another category, we included the specification "map" and the number of springs or sedimentary deposits of salt, according to each case. The pits were represented throughout the study by a unique symbol. In all other cases, for the number of salt water springs or unexploited sedimentary deposits of salt, as well as for the cases where the map provides information other than the one in the repertoire that we presented as such above, see the map section included in Appendix A.

Wallachia

Salt mines (“Salzgruben"): OKNA KIMPINA <OKNA BEY KIMPINA>, OKNA RIMNIK <OKNA BEY RIMNIK>, TELEAGA <OKNA TELEAGA>.

Sedimentary deposits of salt (“Salzspurien”): FOCSIAN <FOCRIAN> (one deposit), TERGOVISTA $<$ TERGOVIST> (one deposit).

Salt spring ("Salzbrunnen"): FOCSIAN <FOCRIAN> (map, one salt spring), OKNA KIMPINA <OKNA BEY KIMPINA> (map, two salt spring), OKNA RIMNIK <OKNA BEY RIMNIK> (map, two salt springs).

\section{Moldavia}

Salt mines ("Salzgruben"): OKNA <MOLDAUISCH OKNA>.

Sedimentary deposits of salt (“Salzspurien”): GROZESD (one deposit), HERSAN (map only, one deposit), M[ONS] KETSKETS <KECSKÉSHHAVAS> (one deposit), M[ONS] KIS HAVAS <KISS HAVAS> (deposit unsigned), M[ONS] SIROs (map only, one deposit), VRANTZA PUTNA FL[Uss] <VRANTSA PUTNA FLUSS > (one salt spring only, deposit unsigned).

Salt springs (“Salzbrunnen"): GROZESD (map, one salt spring), HERSAN (map only, one salt spring), KRUTZE < KRUTSE> (two salt springs), M[ONS] KIS HAVAS <KISS HAVAS> (one salt spring only, deposit unsigned), OJTOS FL[USs] (map only, one salt spring), OKNA <MOLDAUISCH OKNA> (one salt spring), PASSUS GYÉMES (map only, one salt spring), pASSUS OJTOS (map only, one salt spring), PURTIESTJ < PORTIESTI> (two salt springs), SZLATINA <SLATINA> (two salt springs), SZUTSAVITZA <SZUTSOVITZA> (two salt springs), VRANTZA PUTNA FL[USS] <VRANTSA PUTNA FLUSS> (one salt spring only, deposit unsigned), zABOLA PUTNA FLUSS (two salt springs).

\section{Transylvania}

Salt mines (“Salzgruben"): DEESÖKNA 〈DESAKNA〉, KÓLOS, PARAJD <PARAYD>, RHENASZEK $<$ RHONASZEK>, SZEK, THORDA, VISZAKNA.

Sedimentary deposits of salt (“Salzspurien”): A[LSÓ] IDETS, A[LSÓ] SUK <ALSO-SUG>, BELLÁK <BILLAK>, DRAGOM[IRFA]LV[A] <DRAGOMIR>, F[ELSÖ] SUK <FELSÖ-SUG>, FELSÖ BAJOM, KOROND, KÖTELEND, KÖVAR (map, one deposit), KUKÜLLÖ KEMENYF[AL]V[A], LIPSE BACH 〈LIPSE FLUSS> (deposit unsigned), MAROS UIVAR <MAROSUJVAR>, MIHALIKA, NAGY ERNYE <NAGY-ERENYE >, <OLAH PINTEK>, ORSOVA, OVASZFALA <GÖRGÉNI-OROSZFALU>, PASZMOS <PASSMOS>, PATA, REMETE, districtul Chioar (map, one deposit), 〈PETERFALVA> (Count of Tîrnava), 〈SAJO-Udvarhely> (inaccurately included in the County of Dăbîca), s[ZEN]T IMREH <GÖRGÉNI-SZENT IMRE/SZENTIMRE〉, SOOFALVA 〈SÓFALVA〉, SZ[ÁSZ] NYIRES, SZ[EN]T PALL <HOMOROD-SZENT PAL〉, SZABANITZA 〈SOAKNA〉, SZASZ REGEN, SZEPLAK (map, one deposit), SZOVATHA 〈SZOVATA〉, TEKE <TEKENDORFF>, UDVARHELLY, VRANTZA PUTNA FL[USS] 〈VRANTSA PUTNA FlUSS> (deposit unsigned), ZABOLA PUTNA FLUSS (three deposits).

Salt springs (“Salzbrunnen”): A[LSÓ] IDETS, <ALSO-RÁKOSD>, A[LSÓ] SUK <ALSO-SUG>, ABOCSFALVA <ABOSFALVA>, ALMAS, ASZN BESZTERIZE <ASZU BESZLERCZE〉, BALASF[Á]L[VA], BALLA, BATOS, BELLÁK <BILLAK>, BETHLEN, BONTZ NYIRES <BONCZ-NYIRES>, BORZAS, BÖZZOD <BÖSÖSD>, <BUZASBOCSARD>, CSEPAN, DEES, DEZMER 〈DESMÉR>, ERDÖ SZAKAL 〈ERDÖSSAKAL〉, F[ELSÖ] BORGO, F[ELSÖ] SUK 〈FELSÖ-SUG〉, FEJEREGYHAZ <FEHÉREGYHÁZA〉, FEKETELAK, FELSÖ BAJOM, <FIATFALVA>, FÜGE, GALD, <GALFALVA>, GARAD, GRID (map only, two salt springs), GYEPES <KOPIS>, 
HADAT (two salt springs), HESDAAD <HÉSDÁT>, HESTAD <HÉSDÁT>, HOLDAU <HELTAU> (with the indication ,,ist vertilget" [it is exhausted]), <IKLOD>, J[OSENI?] BORGO, <ALSO-BORGO >, JAD <IAAD>, KAILA < KAYLA>, KARATSONFALVA, KEMENYFALVA < HOMOROD-KEMÉNYFALVA>, KENDTELKE <KENTELKE >, KERESZTURF[A] L[VA], KINTSES, KIS AKNA (map only, two salt springs), K[IS] DÖGMEZÖ <DÖGMEZÖ>, K[IS] KAIAN <KIS-KAJON>, KIS SÁROS <KISS-SÁROS>, KISFALU (map only, two salt springs), 〈KISS-ALMAS〉, 〈KISS-OESKÜLLÖ〉, KOROND, KÖSZV[ÉNYES] 〈KÖSSVÉNYES〉, KÖTELEND, KÖVAR (map only, one salt spring), KÖZEPF[A]L[VA], KÜKÜLLOVAR, LÉTKA, LÖVETE, 〈MAGOSMART>, MAGYAROS (County of Dăbîca), MAGYaros (County of Turda), MALLOMARKA <MALOMÁRKA>, MÁlON <MALOM>, MAROS UIVAR <MAROSUJVAR>, MEZÖ MADARAS, MIKEHAZO <MIKEHAZA>, MIKES, N[AGY] DEMETER, NAGY ERNYE 〈NAGY-ERENYE〉, N[AGY] IDA, 〈NAGY-KAJON〉, NAGY LOZNA 〈NAGY LÓSSNA〉, $\mathrm{N}[\mathrm{AgY}]$ OSKÜLLA 〈NAGY OESKÜLLO>, NEMEGYE <MAGYAR-NEMEGYE AND OLAHNEMEGYE〉, NET <NÉZ〉, OKNITZA 〈SZASZAKNA〉, 〈OLAH PINTEK〉, ORSOVA, OVASZFALA <GÖRGÉNIOROSZFALU> [= Oroszfája], PASSUS BOOZA (map only, one salt spring), PASSUS RODNA (map only, one salt spring), PASS[US] TÖMÖs (map only, one salt spring), PASSUS TORZBURG (map only, one salt spring), PASZMOS <PASSMOS>, PERSAN (map only, two salt springs), PETERFALVA (County of Alba), PINTAK <SZASZ-PINTEK>, REMETE (District of Chioar), REMETE (Seat of Mureș), REPS, RETSENYED, ROTHE THURN PASS[US] (map only, one salt spring), RUSZ-BORGO <OROSZ-BORGO>, <SAJO KERESSTUR>, 〈SAJO-UDVARHELY>, SAMSAND <SAMSON>, SEPTER, SOM KER[EK] <SOMKEREK>, SOMKUT, SOOFALVA <SÓFALVA>, SOSPATAK <SOOSPATAK>, SOVAROD, SZABAD, SZABANITZA <SOAKNA>, SZEPLAK (one salt spring), SZ[ÁSZ] NYIRES, 〈SZENT-ANDRÁS>, S[ZEN]T IMREH <GÖRGÉNI-SZENT IMRE/ SZENT-IMRE>, S[ZENT] MARGITTA, SZ[ENT] MARTON (Seat of Ciuc), <SZENT-MARTON> (County of Turda), sZ[ENT] MARTON <HOMOROD-SZENT MÁRTON>, s[ZEN]T MIKLOS <SCENT MIKLOS>, s[ZEN]T PETER < HOMOROD-SZENT PÉTER>, <SZESZARMA〉, SZIMONTELKE <SIMONTELKE〉, SZITAS KERESZTUR, SZOMBATTELKE, SZOTELKE <SÓTELKE>, SZOTZ BANYITZA <SZASZ-BANITZA>, TEKE <TEKENDORFF $>$, TOHAT (County of Solnocul Interior), TOHAT (County of Alba de Jos; map only, two salt springs), TOR[PÉNY] <TREPPEN>, UDVARHELLY, VAJOLA <WOJOLA>, VET <WETS>, VINDA <WAAD>, 〈VIRÁGOSBEREK>, ZEREDFADA <SZERETFALVA〉.

\section{Conclusions}

The identification of the present correspondents of toponyms in Fichtel's map represents a material available for the research of the history of salt exploitation on the territory of Romania, especially for the Transylvania region. A monograph dedicated to the history of salt mines in the modern era of Moldavia was elaborated by Vitcu (1987). The exploitation of salt in Transylvania offers a much richer history, one of the necessary steps being this specific equation of the nomenclature during the Hungarian administration with the present one. The aim of the present study did not include the explanation of certain versions that are not simple graphic deformations such as, for instance, the variation Tergovista/ Tergovist, where - a is the feminine definite article representing the gender agreement with cetate "citadel", or the Hungarian semi-calque Orosz-Borgo and the transliteration Rusz-Borgo. Localizations on Fichtel's map (elaborated in collaboration with Carl Gabriel Wappler) have a high degree of accuracy for the time when the map was conceived. The positioning of only three localities is visibly misplaced: Szeplak (misplaced towards the East), Ovaszfala (misplaced towards the South-East), and Septer (misplaced towards the North-East). Appendix A represents the area of Transylvania on Fichtel's map. Mihalika was identified with Ocna Mihai "Mihai Salt Mine", according to its position on the map. 


\section{Bibliography}

\section{A. References}

Ackner, M.J. (1856). Die Römischen Alterthümer und deutschen Burgen in Siebenbürgen, in "Jahrbuch der Kaiserlich Königlichen Central-Comission zur Erforschung und Erhaltung der Baudenkmale”, II. Abtheilung, Wien, p. 3-50.

Ackner, M.J. \& Müller, F. (1865). Die römischen Inschriften in Dacien, Tendler, Wien.

Christescu, V. (2004). Viața economică a Daciei Romane, Ars Docendi, București (ed. I-a: 1929).

Ciobanu, D. (2002). Exploatarea sării în perioada marilor migrații (sec. I-XIII e.n.) în spațiul carpato-dunărean, Biblioteca Mousaios, Buzău.

Dana, D. \& Zăgreanu, R. (2013). Deux dédicaces latines inédites de Porolissum, in "Tyche. Beiträge zur Alten Geschichte, Papyrologie und Epigraphik", vol. 28, p. 27-35, Crossref.

Doboși, A. (1951). Exploatarea ocnelor de sare din Transilvania în evul mediu (sec. XIV-XVI), in "Studii și cercetări de istorie medie", p. 125-166.

Fichtel, I.E. von (1780). Geschichte des Steinsalzes und der Steinsalzgruben im Grossfürstenthum Siebenbürgen, mit einer, das Streichen des unterirrdischen Salzstockes, durch mehrere Länder andeuten den Karte, und andern Küpfern, Kaspischen Verlag, Nürnberg, Crossref.

Fischer, G. (1921). Zwei römische Inschriften aus Billak bei Bistritz, in "Korrespondenzblatt des Vereins für siebenbürgische Landeskunde", XLIV/7-12, p. 67-72.

Gooss, C. (1876). Chronik der archäologischen Funde Siebenbürgens, in “Archiv des Vereins für siebenbürgische Landeskunde”, 13/II, p. 203-338.

Maghiar, N. \& Olteanu, Șt. (1970). Din istoria mineritului în România, Editura Științifică, București.

Mihăilescu-Bîrliba, L. (2016). Remarques sur le personnel de l'administration des salines en Dacie Romaine, in "Studia Antiqua et Archæologica”, XXII/1, p. 51-58.

Opitz, M. (2009). Briefwechsel und Lebenszeugnisse: kritische Edition mit Übersetzung, ed. Klaus Conermann, Walter de Gruyter, Berlin/New York (ed. I-a: 1611-1642).

Pascu, Șt. (1986). Voievodatul Transilvaniei, III, Editura Dacia, Cluj-Napoca.

Piso, I. (2004-2005). Un nouveau conductor salinarum en Dacie, in “Acta Musei Napocensis”, 41-42, p. 179-182.

Suciu, C. (1967). Dicționar istoric al localităților din Transilvania, vol. I-II, Editura Academiei, București.

Treuenfeld, I. L. von (1839). Siebenbürgens geographisch-, topographisch-und orographisches Lexikon, Wien.

Vitcu, D. (1987). Istoria salinelor Moldovei în epoca modernă, in "Anuarul Institutului de istorie și arheologie «A.D. Xenopol»", Supliment IX, Iași.

Wollmann, V. (1996). Mineritul metalifer, extragerea sării și carierele de piatră în Dacia Romană / Der Erzbergbau, die Salzgewinnung und die Steinbrüche in römischen Dakien, Bibliotheca Musei Napocensis, Klausenburg/Cluj-Napoca.

Zamosius, S. (1593). Analecta lapidum vetustorum et nonnullarum in Dacia antiquitatum, Pataviæ.

\section{B. Sources}

CDEM I = Codex diplomaticus et epistolaris Moravie. Tomus primus. Studio et opera Antonii Boczek, Skarnitzl, Olomucii, 1836. CIL III = Corpus Inscriptionum Latinarum. Vol. III, Inscriptiones Asie, provinciarum Europe Grecarum, Illyrici Latine, ed. Th. Mommsen, Berolini, 1873.

DIR,C I = Documente privind istoria României. C. Transilvania, veacurile XI, XII și XIII, vol. I, Editura Academiei, București, 1951.

IDR III = Inscripțiile Daciei Romane, vol. III, ed. Ioan I. Russu, Editura Academiei, București, 1984 (III/3), 1988 (III/4); ed. I.

Piso, Ed. Frères Boccard, Paris, 2001 (III/5). 


\section{Appendix A.}

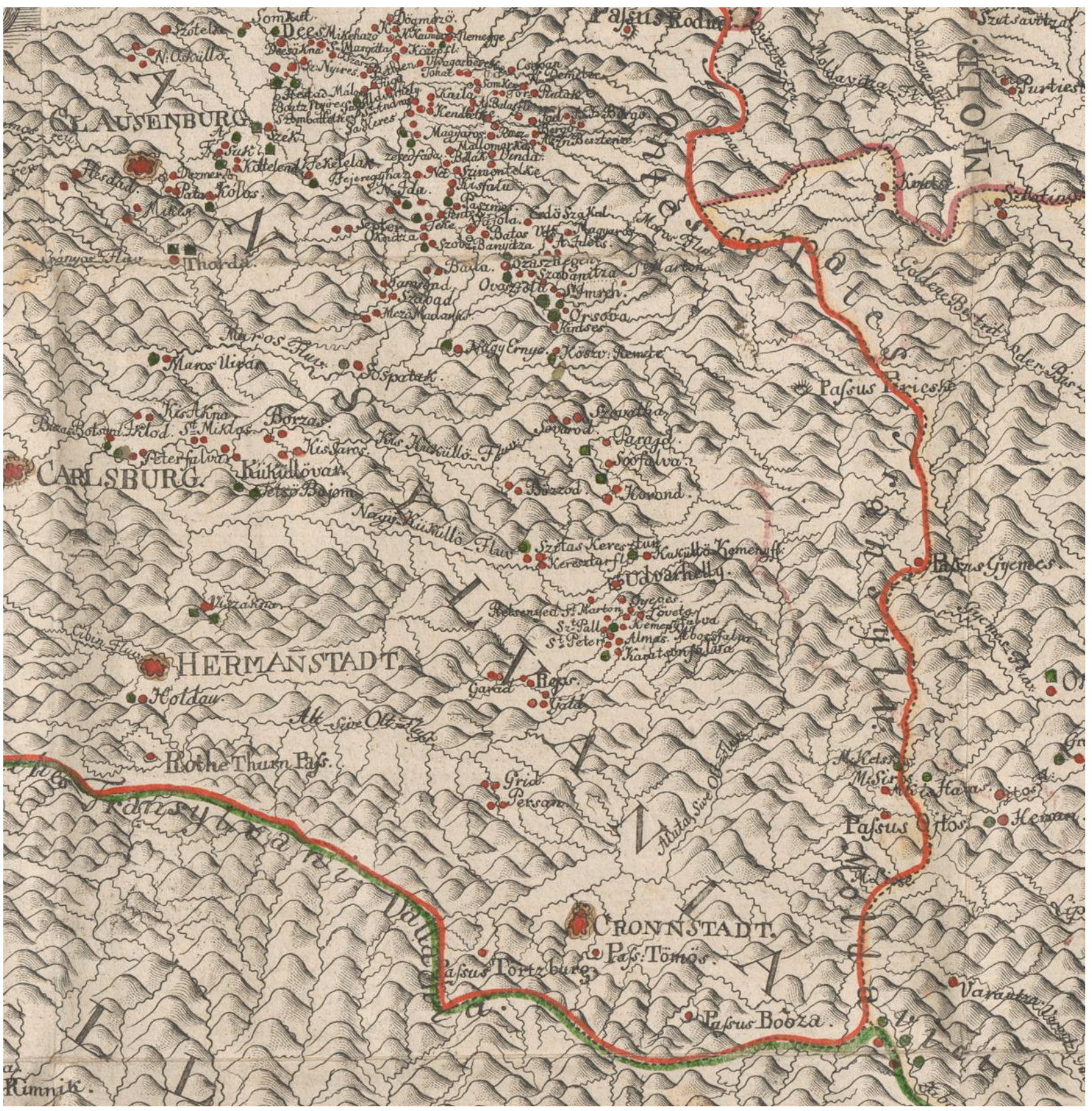

Figure A.1: Section of Fichtel's map (PLAN der andeütet, wie der Unterirrdische-Salz-Stok, von der Wallacheÿ angefangen, durch die Wallachey Moldau, Siebenbürgen, Hungarn und Pohlen, bis nach Vieliczka und Pochnia in Pohlen und bis Sowar in Hungarn längst der Karpatischen Gebürge fort streichet). 